\section{To: (Receiving Organization)} Distribution

5. Proj./Prog./Dept./Div.:

Spent Nuclear Fuel Project/Sludge Treatment

8. Originator Remarks:
3. From: (Originating organization) Numatec Hanford Corporation/Sludge Treatment

6. Design Authority/ Design Agent/Cog. Engr.:

T. A. Flament
4. Related EDT No.:

625261

7. Purchase Order No.:

N/A

\begin{tabular}{|l|l|l|}
\hline 8. Originator Remarks: & $\begin{array}{l}\text { 9. Equip./Component No.: } \\
\text { N/A }\end{array}$ & $\begin{array}{c}\text { 10. System/Bldg./Facility: } \\
\text { N/A }\end{array}$ \\
\hline 11. Receiver Remarks: & 11A. Design Baseline Document? [] Yes [X] No & $\begin{array}{c}\text { 12. Major Assm. Dug. No.: } \\
\text { NA }\end{array}$ \\
\cline { 3 - 4 } & $\begin{array}{c}\text { 13. Permit/Permit Application No.: } \\
\text { NA }\end{array}$ \\
14. Required Response Date: \\
NA
\end{tabular}

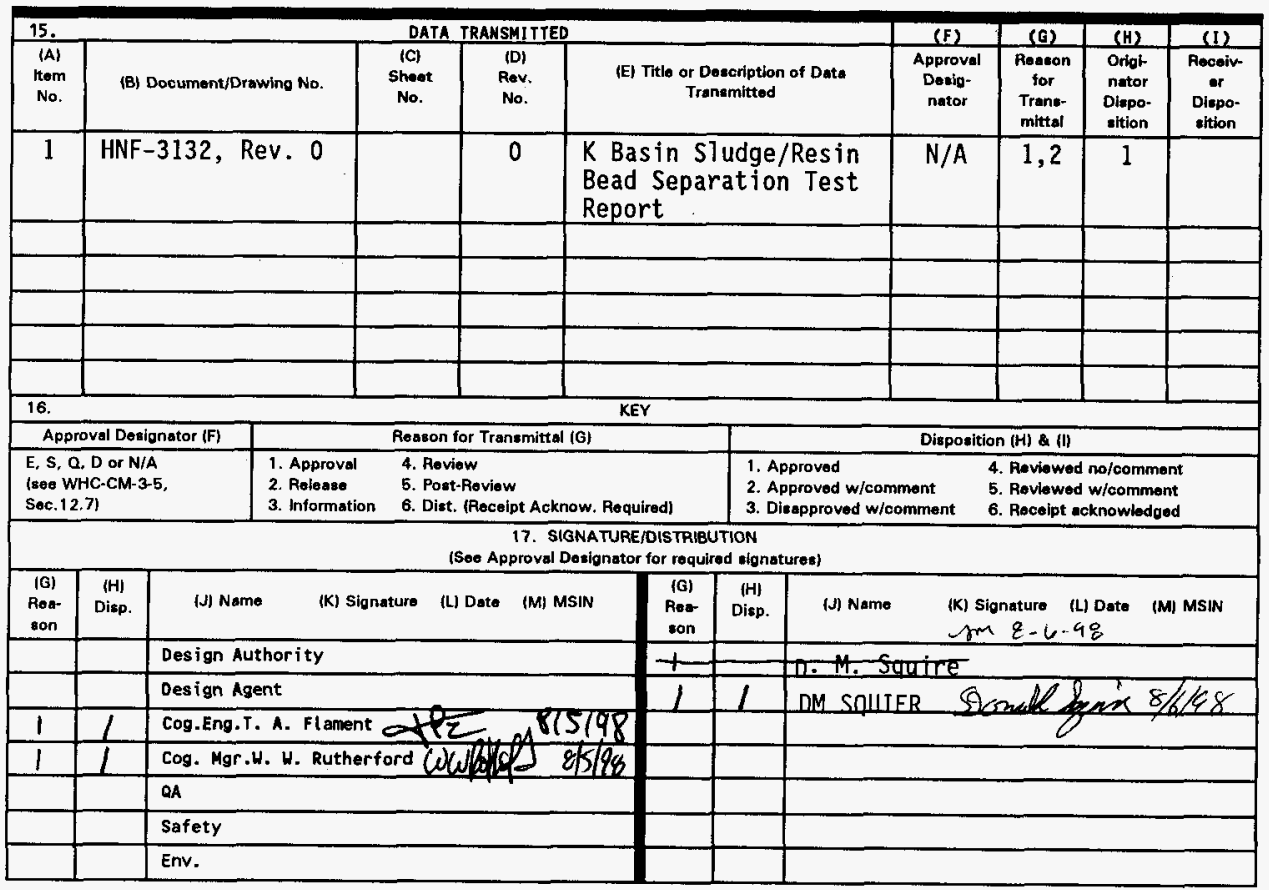

\begin{tabular}{|c|c|c|}
\hline $\begin{array}{l}18 . \\
\text { T. A. Flament }\end{array}$ & & 19. \\
\hline $\begin{array}{l}\text { Signature of EDT } \\
\text { Originator }\end{array}$ & Date & $\begin{array}{l}\text { Authorized Representativo Dato } \\
\text { for Recoivina Organization }\end{array}$ \\
\hline
\end{tabular}

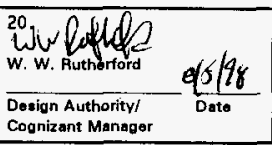

21. DOE APPROVAL (if required) Ctrl. No.

[ ] Approved

[ ] Approved w/comments

[ ] D isapproved w/comments 


\section{K BASIN SLUDGE/RESIN BEAD SEPARATION TEST REPORT, REV. 0}

D. Squier

Numatec Hanford Corporation, Richland, WA 99352

U.S. Department of Energy Contract DE-AC06-96RL13200

EDT/ECN: 625261

Org Code: 8C700

UC: 2000

B\&R Code: EW7040000

Charge Code: LD451 HANA2600

Total Pages: 34

Key Words: Sieved, Resin Bead, Simulant, Elutriation

Abstract: Experiments with simulants have demonstrated that it is possible to extract a nominal $95 \%$ resin bead mass in an elutriation column with a nominal $3.8 \mathrm{~cm} / \mathrm{s}$ water flow rate. The non-bead sludge component entrained with the separated beads range from 0.15 to 1.4 percent of the total sludge dry mass. The percentage of solids entrained with the beads depends on the type of screen (125 or 300 microns) used before the elutriation column.

IRADEMARK DISCLAIMER. Reference herein to any specific comercial product, process, or service by trade name, trademark, manufacturer, or otherwise, does not necessarily constitute or imply its endorsement, recommendation, or favoring by the United States Government or any agency thereof or its contractors or subcontractors.

Printed in the United States of America. To obtain copies of this document, contact: Document Control Services, P.O. Box 950, Mailstop H6-08, Richland WA 99352, Phone (509) 372-2420; Fax (509) 376-4989.

$\frac{\text { Chustivi Stülexigham 8-25-98 }}{\text { Release Approval }}$

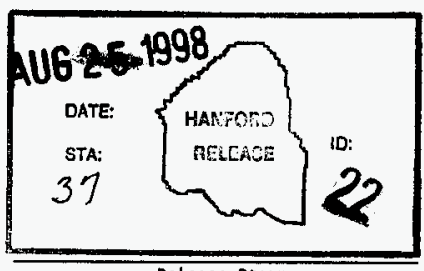

Release stamp 


\title{
K BASIN SLUDGE/RESIN BEAD SEPARATION TEST REPORT
}

\author{
August 1998 \\ Don Squier \\ Numatec Hanford Corporation \\ Richland, Washington \\ Issued by \\ NUMATEC HANFORD CORPORATION \\ for the \\ U.S. DEPARTMENT OF ENERGY \\ RICHLAND OPERATIONS OFFICE \\ RICHLAND, WASHINGTON
}


K Basin Sludge/Resin Bead Separation Test Report, HNF-3132, Rev. 0

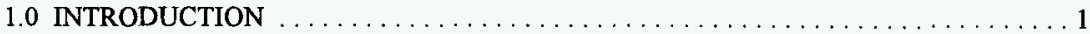

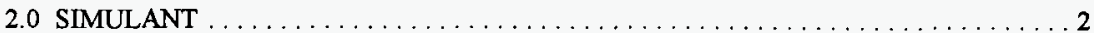



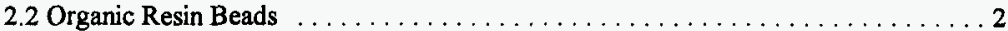

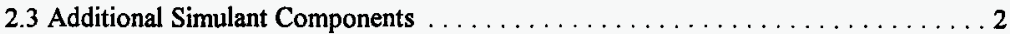

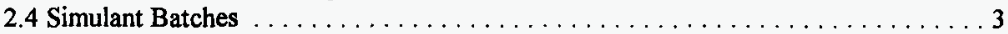

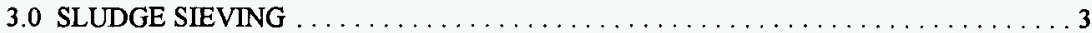

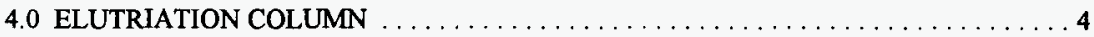

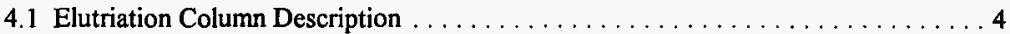

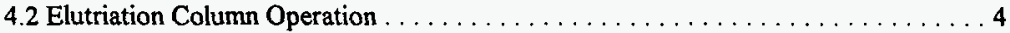

4.3 Flow Rate Calibration ......................... 5

4.4 Resin Bead Yield per Column Flow Rate .................... 5

5.0 POST RUN OPERATIONS AND MEASUREMENTS $\ldots \ldots \ldots \ldots \ldots \ldots \ldots$

6.0 RESIN BEAD SEPARATION RESULTS $\ldots \ldots \ldots \ldots \ldots \ldots \ldots \ldots \ldots \ldots$

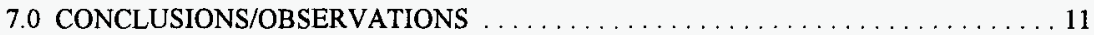

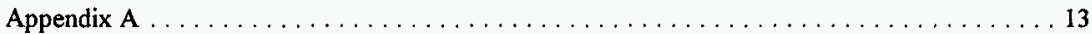

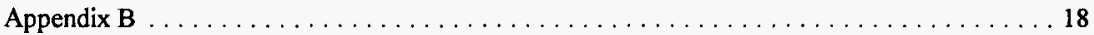

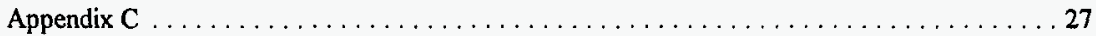

Appendix D . . . . . . . . . . . . . . . . . . 28

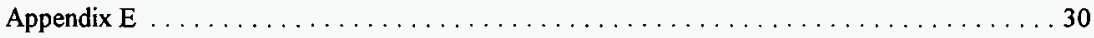




\section{TABLES}

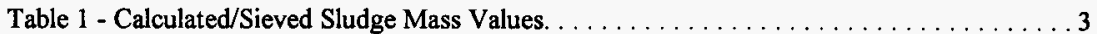

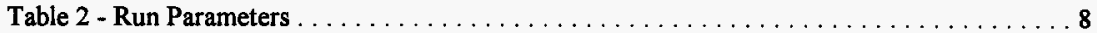

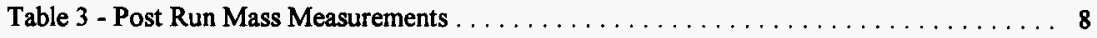

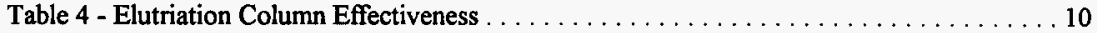

Table 5 - Total Simulant Mass Balance $\ldots \ldots \ldots \ldots \ldots \ldots \ldots \ldots \ldots \ldots \ldots$

\section{FIGURES}

Figure 1 - Elutriation Column $\ldots \ldots \ldots \ldots \ldots \ldots \ldots \ldots \ldots \ldots \ldots \ldots \ldots \ldots$

Figure 2 - Elutriation Colum Resin Bead Yield $\ldots \ldots \ldots \ldots \ldots \ldots \ldots \ldots \ldots \ldots$

Figure 3 - Resin Bead Yield from Simulant . . . . . . . . . . . . . . . . . . . . . . 9 


\section{K Basin Sludge/Resin Bead Separation Test Report, HNF-3132, Rev. 0}

\subsection{INTRODUCTION}

The $\mathrm{K}$ Basin sludge is an accumulation of fuel element corrosion products, organic and inorganic ion exchange materials, canister gasket materials, iron and aluminum corrosion products, sand, dirt and minor amounts of other organic material. The sludge will be collected and treated for storage and eventual disposal. This process will remove the large solid materials by a $1 / 4$ inch screen. The screened material will be subjected to nitric acid in a chemical treatment process. The organic ion exchange resin beads produce undesirable chemical reactions with the nitric acid. The resin beads must be removed from the bulk material and treated by another process. An effective bead separation method must extract $95 \%$ of the resin bead mass without entraining more than $5 \%$ of the other sludge component mass.

The test plan HNF-2729, "Organic Ion Exchange Resin Separation Methods Evaluation," proposed the evaluation of air lift, hydro cyclone, agitated slurry and elutriation resin bead separation methods. This follows the testing strategy outlined in section 4.1 of HNF-2574, "Testing Strategy to Support the Development of K Basins Sludge Treatment Process".

Engineering study HNF-3128, "Separation of Organic Ion Exchange Resins from Sludge", Rev. 0, focused the evaluation tests on a method that removed the fine sludge particles by a sieve and then extracted the beads by means of a elutriation column.

Ninety-nine percent of the resin beads are larger than 125 microns and 98.5 percent are 300 microns and larger. Particles smaller than 125 microns make up the largest portion of sludge in the K Basins. Eliminating a large part of the sludge's non-bead component will reduce the quantity that is lifted with the resin beads in the elutriation column. Resin bead particle size distribution measurements are given in Appendix A

The Engineering Testing Laboratory conducted measurements of a elutriation column's ability to extract resin beads from a sieved, non-radioactive sludge simulant. A elutriation column uses a constant velocity upward flow stream to segregate materials. In simplistic terms, the dense particles fall to the column's bottom while the flow lifts less dense particles to the column's top. A particle can be streamlined or have a high drag profile; this factor also influences the lift or fall of a particle exposed to the column flow. The sludge components that lift or fall are determined by the fluid velocity.

The column flow velocity needed to lift the bulk of the resin beads will also lift other, non-bead, sludge components. Resin bead treatment and disposal are complicated by large quantities of non-bead material. Tests are necessary to determine a column flow velocity that will collect the bulk of the resin beads and the amount of non-bead sludge components that are also collected. Measurements will compare the effect of elutriation column runs using minimum particle sizes of 125 microns and 300 microns on the mass percent of non-bead material lifted with the beads. 


\section{K-Basin Sludge/Resin Bead Separation Test Report, HNF-3132, Rev. 0}

\subsection{SIMULANT}

\subsection{Sludge Simulant}

The sludge simulant composition is based on a description provided in Numatec Hanford Corporation internal memo, "Sludge Simulant for Organic Ion Exchange Resin Separation," 8C720-98-JBD:001 (see Appendix B). The simulant components are aluminum oxide, iron oxide, copper (simulates uranium oxide), mixed bed resin beads and blow sand obtained beside the road north of the Hanford site's 300 Area. The resin beads and copper particles were the only simulant components that were used in the supplied particle sizes. The remaining components were sieved into eight particle sizes to emulate the particle size/mass percentages detailed in the memo. These components required ball milling to obtain enough of the fine particles.

\subsection{Organic Resin Beads}

Purolite, NRW-37, nuclear grade mixed bed resin beads were used in this test series. The resin beads were stored under water to maintain their swollen wet diameters. This condition mimics resin beads in a sludge quantity freshly retrieved from the $\mathrm{K}$ Basins. The wet condition poses some problems and special procedures for mass measurements. The bulk of the water is removed by exposure to a vacuum filtration system for 30 seconds. The beads are then placed on a tared weighing pan and subjected to an evacuated bell jar for five minutes. The bead mass drops continuously while resting on a balance; apparently the water readily evaporates from the beads. For this reason, the beads are weighed immediately after removal from the bell jar to maintain a consistent measurement method. This procedure is used for all resin bead mass measurements.

\subsection{Additional Simulant Components}

The sludge simulant is based on samples that had passed through a 700 micron sieve. The seive removes 10 to $20 \%$ of the original mass in the form of large particles. The sludge retrieval process may collect particles larger than 700 microns. These large particles may be lifted in the column and collect with the resin beads. Large sand particles are added to a simulant batch to test this possibility. Sand is a lighter sludge component and represents a worst case condition.

Zeolite is also present in the $\mathrm{K}$ basin sludge, but is not included in the simulant. Zeolon 900 was added to a sludge batch to measure the effects of zeolite.

ZEOLON is a registered trademark of Norton Company 


\section{K-Basin Sludge/Resin Bead Separation Test Report, HNF-3132, Rev. 0}

\subsection{Simulant Batches}

The simulant batches contained 120 grams or 134 grams of dry components. A unique number is assigned to each simulant batch. The column runs are identified by an $\mathrm{S}$, followed by the simulant batch number used for the run. Appendix $C$ contains additional information on the sludge simulant components and a table listing the particle sizes, masses and components of each batch used in this test series.

\subsection{SLUDGE SIEVING}

The dry sludge components were mixed with an arbitrary amount of water and then placed onto a 125 or 300 micron sieve. The fine simulant particles were washed through the sieve by a stream of water and collected in a tared beaker. The water was driven from the fines in a $110^{\circ} \mathrm{C}$ oven so the residue mass could be measured in the beaker. The simulant not passing though the sieve is run through the elutriation column.

The theoretical amount of material passing through the screen can be calculated by summing the component masses with particle sizes smaller that the sieve size. Table 1 compares the dried through sieve material mass with the calculated mass. The calculated and measured masses are within a fractional percent in every batch.

\begin{tabular}{|c|c|c|c|c|c|c|c|}
\hline & \multicolumn{7}{|c|}{ Table 1. Calculated/Sieved Sludge Mass Values } \\
\hline & \multicolumn{4}{|c|}{ Total grams, particles less than 125 microns } & \multicolumn{3}{|c|}{$\begin{array}{c}\text { Total grams, particles less than } \mathbf{3 0 0} \\
\text { microns }\end{array}$} \\
\hline & \multicolumn{7}{|c|}{ Sludge Simulant Batch } \\
\hline & 1 & 2 & 3 & 9 & 4 & 10 & 11 \\
\hline $\begin{array}{l}\text { Calculated } \\
\text { Sludge Mass } \\
\text { Passing Through } \\
\text { Screen }\end{array}$ & 96.002 & 95.994 & 96.009 & 96.005 & 99.732 & 99.732 & 99.729 \\
\hline $\begin{array}{l}\text { Grams of } \\
\text { screened dried } \\
\text { sludge simulant }\end{array}$ & 96.4 & 96.78 & 96.77 & 95.15 & 100.18 & 99.4 & 100.6 \\
\hline $\begin{array}{l}\% \text { of Calculated } \\
\text { Material } \\
\text { Actually } \\
\text { Recovered }\end{array}$ & 100.4 & 100.8 & 100.8 & 99.1 & 100.4 & 99.7 & 100.9 \\
\hline
\end{tabular}




\subsection{ELUTRIATION COLUMN}

\subsection{Elutriation Column Description}

Figure 1 is an image of the elutriation column test apparatus. The column is constructed of $34.67 \mathrm{~mm}$ inside diameter acrylic tubing with a length of $189.9 \mathrm{~cm}$ from the inlet at the bottom collection chamber to the column outlet's lowest elevation. The column outlet directs water and sludge particles to the top collection chamber. A standpipe in this chamber permits water to overflow into the reservoir below while collecting the sludge particles lifted by the column's upward flow.

Water is drawn from the reservoir by a variable flow pump. The water is pumped through a rotameter before it is discharged into the bottom collection chamber for recirculation through the column.

Sludge particles not lifted by the flow of the column will fall into the bottom collection chamber. The relatively large diameter of this chamber reduces the velocity of the flowing water so the particles will stay in the chamber rather than rise into the column.

\subsection{Elutriation Column Operation}

A run begins without water in the column. A hose conducts filtered de-ionized water from the ETL K-Basin mockup pool into the upper end of the column. The water is run until it flows from the outlet, fills the top collection chamber and half of the reservoir. Air is expelled from system by running the pump at an elevated flow rate. The flow is then adjusted to the rate required for the run.

Sludge is introduced into the column through a funnel elevated above the column's outlet. Tubing connects the funnel to an elbow fitting that penetrates the column $82.9 \mathrm{~cm}$ above the bottom collection chamber. A quantity of water following the sludge forces the mixture into the flow stream of the column.

The magnetically coupled gear pump must slip under the load



Figure 1. Elutriation Column for it is necessary to monitor and continuously adjust the flow rate throughout the run. Particles continue to circulate in the column's mid- elevation when no additional particles are observed 


\section{K-Basin Sludge/Resin Bead Separation Test Report, HNF-3132, Rev. 0}

passing through the column outlet. The run is ended under these conditions by shutting off the pump. The circulating particles then fall into the bottom collection chamber.

The column is drained by removing the tubing from the rotameter outlet and directing the tubing end to a collection vessel resting on the floor. This drains the water down to the bottom collection chamber's top. The bottom collection chamber may then be removed by loosening the four C-clamps that fasten it to the column flange.

\subsection{Flow Rate Calibration}

A volume flow rate calibration was performed on the rotameter after completing the elutriation column activities. This approach permitted the calibration data to be focused on the flow indication range used in the test series. Appendix D contains a description of the volume flow rate calibration, the calibration data, and conversion of the volume flow rate into column flow velocity.

\subsection{Resin Bead Yield per Column Flow Rate}

The elutriation column was fitted with an uncalibrated rotameter (flow rate instrument) that indicated 0 to $100 \%$. The initial column runs were made to determine a flow rate indication that would lift 95 mass percent of the resin beads to the top collection chamber. A column flow rate was established, then a mass of resin beads were introduced into the column to separate into the top or bottom collection chambers. The beads in each collection chamber were dried and weighted so the mass percent lifted could be calculated using the sum of both masses as the $100 \%$ value. This process was repeated to obtain flow indications above and below the $95 \%$ bead yield value. The data values are contained in Appendix E.

Figure 2 is a plot of the elutriation column bead yield at various flow rates. The equation for the fitted line has a high correlation coefficient with the data points. Lines on the figure show the three flow rates used in the elutriation column sludge simulant tests and expected bead yields. The middle flow rate was selected because it is near the $95 \%$ bead yield and corresponds to the rotameter's 50\% flow graduation. The maximum and minimum flow rates correspond to the next graduations above and below the $50 \%$ graduation. 


\section{K Basin Sludge/Resin Bead Separation Test Report, HNF-3132, Rev. 0}

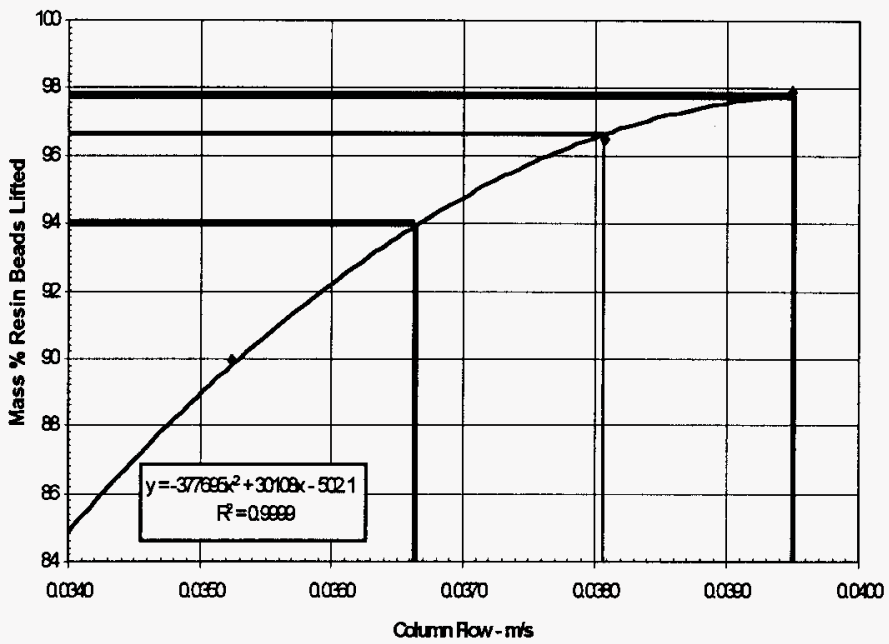

Figure 2. Elutriation Column Resin Bead Yield

\subsection{POST RUN OPERATIONS AND MEASUREMENTS}

The beads must be separated from the non-bead material in both the top and the bottom collection chambers so the four quantities of material can be dried and weighted. The material is rinsed from a collection chamber and into a beaker. The reservoir also collects some material lifted by the column so these contents must be added to the contents of the top collection chamber.

Some initial bead separation experiments were made using a $70 \%$ by mass sugar solution to float the resin beads. This was an effective resin bead separation method, but it required a lot of time for the beads to rise in the viscous solution. The beads would float in two layers with a space of clear liquid between the layers. Time and resources were not expended on investigating the reason for the two layers. It is speculated that the slight density difference between the anion and cation resin beads would account for the layering.

A sluice box was very effective in removing resin beads from the bulk material separated by the column. The bead's spherical shape rolls off the sluice's lower end while the non-bead material is trapped in the sluice's grooved mat. Zeolon 900 tended to run down the sluice much faster than other sludge components, but just slightly slower than the resin beads. 


\section{K-Basin Sludge/Resin Bead Separation Test Report, HNF-3132, Rev. 0}

The sluice is constructed from a grooved plastic mat. The triangular shaped grooves are 3.175 $\mathrm{mm}$ apart and $1.52 \mathrm{~mm}$ deep. The grooved mat did not have the ideal profile for separating beads. The groove's closely spaced peaks and valleys tended to trap some of the beads. Rounded groove peaks and valleys with wider spacings would promote a spherical bead's ability to roll out of the grooves. The mat is laid in a length of ten inch channel iron so a 0.9 meter long trough is formed with perpendicular grooves. One end of the channel iron is elevated so the sluice has a $6.5^{\circ}$ slope. A bead catch pan is placed at the sluice's lower end.

The sludge mixture is placed on the elevated end of the sluice. A gentle stream of water washes the beads off the sluice and into the catch pan. The washing continues until the non-bead components approach the lower end of the sluice. The beads are then removed from the catch pan by turkey baster suction and transferred into a specimen jar. The material on the upper end of the sluice does not contain beads and is washed into another, non-bead, specimen jar. The material remaining on the mat is consolidated and washed down the sluice again. This process is repeated until no additional beads are separated.

The beads are dried and weighed as previously described. The bulk of the water is removed from the non-bead material by a vacuum filter system operated for thirty seconds. The material is then transferred to a tared weighing pan and exposed to a $110^{\circ} \mathrm{C}$ oven for ten minutes. The nonbead material is then weighed.

\subsection{RESIN BEAD SEPARATION RESULTS}

Table 2 summarizes the seven sludge simulant run parameters. Runs with a minimum particle size of 125 microns (S1, S2, S3 and S9) used column velocities of $0.037,0.038$ and 0.039 meters per second that were expected to respectively yield $94 \%, 96.6 \%$ and $97.8 \%$ resin beads. Runs with a minimum particle size of 300 microns used sludge composition variations and were only run at a column velocity expected to yield $96.6 \%$ of the resin beads. 


\section{K-Basin Sludge/Resin Bead Separation Test Report, HNF-3132, Rev. 0}

\begin{tabular}{|l|l|l|l|l|}
\hline \multicolumn{3}{|c|}{ Table 2. Run Parameters } \\
\hline Run ID & $\begin{array}{l}\text { Simulant } \\
\text { Batch } \\
\text { Number }\end{array}$ & $\begin{array}{l}\text { Minimum } \\
\text { Particle } \\
\text { Size - } \\
\text { Micron }\end{array}$ & $\begin{array}{l}\text { Column } \\
\text { Velocity } \\
\mathrm{m} / \mathrm{s}\end{array}$ & Other Parameters \\
\hline S1 & 1 & 125 & 0.037 & \\
\hline S2 & 2 & 125 & 0.038 & \\
\hline S3 & 3 & 125 & 0.039 & \\
\hline S4 & 4 & 300 & 0.038 & \\
\hline S9 & 9 & 125 & 0.038 & Add sand as follows: 7 grams 840 to 390 micron and 7 grams 590 to \\
\hline S10 & 10 & 300 & 0.038 & 420 micron to standard 120 gram stimulant batch \\
\hline S11 & 11 & 300 & 0.038 & $\begin{array}{l}\text { Add Zeolon 900 as follows: 7 grams 840 to 297 micron, 7 grams 300 } \\
\text { to 420 micron to standard 120 gram stimulant batch }\end{array}$ \\
\hline
\end{tabular}

The post-run simulant mass measurement values are presented in Table 3 below.

\begin{tabular}{|c|c|c|c|c|c|c|}
\hline \multirow{2}{*}{ Run } & \multirow{2}{*}{$\begin{array}{c}\text { Column } \\
\text { Velocity } \\
\mathrm{m} / \mathrm{s}\end{array}$} & \multirow{2}{*}{ Notes } & \multirow{2}{*}{$\begin{array}{l}\text { Column } \\
\text { Collection } \\
\text { Position }\end{array}$} & \multicolumn{2}{|c|}{ Beads } & \multirow{2}{*}{$\begin{array}{l}\text { Non-bead } \\
\text { components } \\
\text { grams }\end{array}$} \\
\hline & & & & $\begin{array}{l}\text { Vacu u m } \\
\text { filtered dry } \\
\text { grams }\end{array}$ & $\begin{array}{l}\text { acu u m } \\
\text { try } \\
\text { grams }\end{array}$ & \\
\hline \multicolumn{7}{|c|}{ Greater than 125 micron particles } \\
\hline \multirow[t]{2}{*}{ S1 } & \multirow[t]{2}{*}{0.037} & & Top & 12.78 & 12.016 & 1.68 \\
\hline & & & Bottom & 0.918 & 0.774 & 6.57 \\
\hline \multirow[t]{2}{*}{$\$ 2$} & \multirow[t]{2}{*}{0.038} & & Top & 13.955 & 12.898 & 1.79 \\
\hline & & & Bottom & 1.436 & 1.195 & 6.64 \\
\hline \multirow[t]{2}{*}{ S3 } & \multirow[t]{2}{*}{0.039} & & Top & 13.78 & 12.88 & 1.77 \\
\hline & & & Bottom & 0.57 & 0.44 & 6.65 \\
\hline \multirow[t]{2}{*}{$\$ 9$} & \multirow[t]{2}{*}{0.038} & \multirow[t]{2}{*}{ Re-Run S2 } & Top & 11.03 & 10.27 & 1.878 \\
\hline & & & Bottom & 2.16 & 1.74 & 7.388 \\
\hline \multicolumn{7}{|c|}{ Greater than 300 micron particles } \\
\hline \multirow[t]{2}{*}{$\$ 4$} & \multirow[t]{2}{*}{0.038} & & Top & 13.61 & 12.75 & 0.18 \\
\hline & & & Bottom & 0.74 & 0.6 & 5.29 \\
\hline \multirow[t]{2}{*}{$\$ 10$} & \multirow[t]{2}{*}{0.038} & \multirow{2}{*}{$\begin{array}{l}\text { Add } 7 \text { grams } 840 \text { to } 590 \text { micron sand and } 7 \\
\text { grams } 590 \text { to } 420 \text { micron sand to standard } \\
120 \text { gram stimulant batch }\end{array}$} & Top & 11.215 & 10.391 & 0.365 \\
\hline & & & Bottom & 1.77 & 1.488 & 18.301 \\
\hline \multirow[t]{3}{*}{ S11 } & \multirow{3}{*}{0.038} & \multirow{3}{*}{$\begin{array}{l}\text { Add Zeolon } 900 \text { as follows: } 7 \text { grams } 840 \text { to } \\
297 \text { mesh, } 7 \text { grams } 300 \text { to } 420 \text { micron to } \\
\text { standard } 120 \text { gram stimulant batch }\end{array}$} & Top & 12.147 & 11.293 & 9 \\
\hline & & & itn & 13 & 29 & ? \\
\hline & & & putumin & 0.49 & 0.20 & 10.074 \\
\hline
\end{tabular}




\section{K-Basin Sludge/Resin Bead Separation Test Report, HNF-3132, Rev. 0}

Figure 3 is a plot of the bead yield at various column flow velocities. The figure shows a line fitted to the initial runs using only the resin beads in the column. The subsequent sludge simulant runs follow the expected bead yield line in four out of seven runs. Malfunctions with the column flow rate indication were noted for the lowest bead yield runs, S9 and S10.

\section{Elutriation Column Bead Yield from Sludge Simulant}

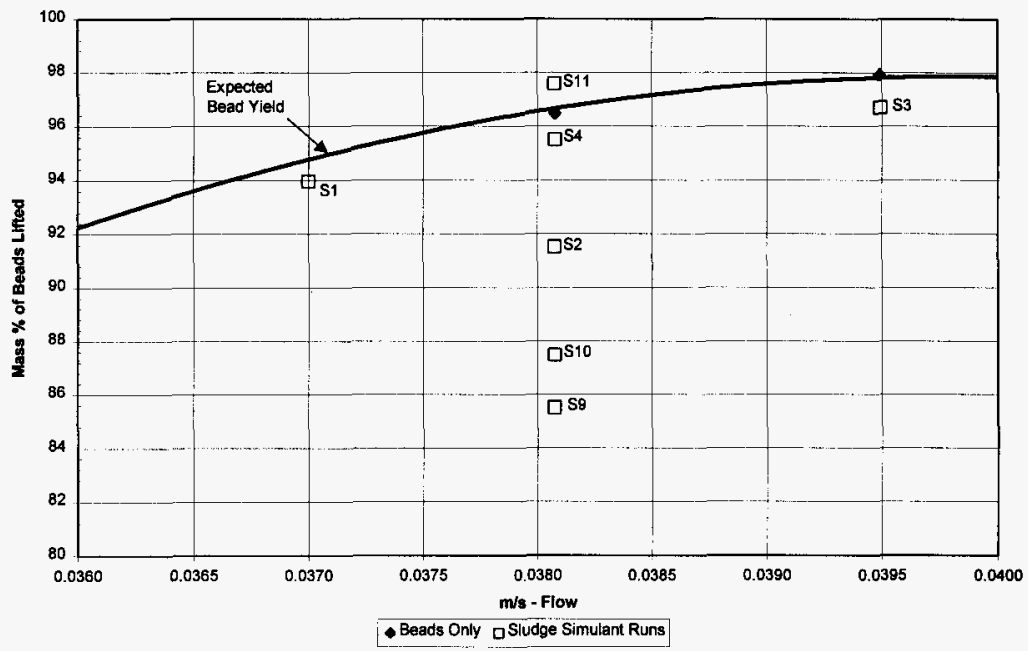

Figure 3. Resin Bead Yield from Simulant

The variable speed pump requires constant adjustment throughout each run to maintain the desired flow. The runs were plagued by problems with the rotameter flow rate indication. Lint would collect on the instrument's float midway into a run and produce higher than actual flow rate indications. The pump speed would then be reduced to maintain the desired flow rate indication. This effect reduces the resin bead yield. The float was also observed to stick when small particles would wedge between the float and sight glass. This condition produces an unknowable effect on the flow rate and bead yield. These limitations produced bead mass percent data that generally are below the amounts predicted by the beads only runs.

Table 4 summarizes a column's ability to remove resin beads from sludge, the amount of nonbead material entrained with the beads and the effect of sieving to control the minimum particle sizes. 


\begin{tabular}{|c|c|c|c|c|c|}
\hline \multirow[t]{2}{*}{ Run } & \multirow[t]{2}{*}{ Notes } & \multirow{2}{*}{$\begin{array}{l}\text { Column } \\
\text { Velocity } \\
\mathrm{m} / \mathrm{s}\end{array}$} & \multirow{2}{*}{$\begin{array}{l}\% \text { Bead } \\
\text { Mass } \\
\text { Lifted in } \\
\text { Column }\end{array}$} & \multicolumn{2}{|c|}{$\begin{array}{l}\text { Mass } \% \text { of non-bead } \\
\text { components lifted in column }\end{array}$} \\
\hline & & & & $\begin{array}{l}100 \%=\text { mass } \\
\text { loaded into } \\
\text { column }\end{array}$ & $\begin{array}{l}100 \%=\text { pre- } \\
\text { sieved dry } \\
\text { simulant } \\
\text { mass }\end{array}$ \\
\hline \multicolumn{6}{|c|}{ Particles Greater than 125 Microns } \\
\hline S1 & & 0.037 & 93.9 & 12.3 & 1.4 \\
\hline S2 & & 0.038 & 91.5 & 12.2 & 1.5 \\
\hline S3 & & 0.039 & 96.7 & 12.1 & 1.5 \\
\hline S9 & Re-Run S2 & 0.038 & $\overline{85.5}$ & 15.5 & 1.6 \\
\hline \multicolumn{6}{|c|}{ Particles Greater than 300 Microns } \\
\hline S4 & & 0.038 & 95.5 & 1.4 & 0.15 \\
\hline S10 & $\begin{array}{l}\text { Add sand as follows: } 7 \\
\text { grams } 840 \text { to } 590 \text { micron } \\
\text { and } 7 \text { grams } 590 \text { to } 420 \\
\text { micron to standard } \sim 120 \\
\text { gram stimulant batch }\end{array}$ & 0.038 & 87.5 & 3.4 & 0.3 \\
\hline S11 & $\begin{array}{l}\text { Add Zeolon } 900 \text { as } \\
\text { follows: } 7 \text { grams } 840 \text { to } \\
297 \text { micron, } 7 \text { grams } 300 \\
\text { to } 420 \text { micron to standard } \\
120 \text { gram stimulant batch }\end{array}$ & 0.038 & 97.6 & $\overline{44.4}$ & 6.7 \\
\hline
\end{tabular}

The amount of lifted non-bead material can be expressed as a percentage of the total simulant mass prior to sieving. This makes it possible to make useful comparisons between runs of different minimum particle sizes. The 125 micron minimum particle size column runs lifted consistent percentages of non-bead components in spite of the poor flow rate control. Eliminating the particles sized between 125 and 300 microns reduced this percentage by a nominal factor of ten as shown by the results of run S4 that used the same simulant composition and a mid-range flow rate. Fourteen grams of sand particles larger than 420 microns added to the sludge simulant in run $\mathrm{S} 10$ only increased the non-bead components lifted by the column a fractional percent relative to run S4. The 14 grams of Zeolon 900 added to batch 11 resulted in the greatest percentage $(6.7 \%)$ of non-bead components lifted by the column in this test series.

Post-test operations require the removal of material collected in the top and bottom chambers of the column. The beads are then separated from the bulk material gathered from each chamber. These four material quantities are then subjected to drying and weighing operations. The operations transfer the material from one container to another leaving some material in the previous container. The result is that the measured mass is less than the actual quantity not exposed to the handing operations. Table 5 expresses the post-run recovered mass as a percentage of the initial simulant batch mass prior to sieving. 


\section{K-Basin Sludge/Resin Bead Separation Test Report, HNF-3132, Rev. 0}

\begin{tabular}{|c|c|c|c|c|c|c|}
\hline Run & Component & $\begin{array}{l}\text { Batch } \\
\text { Mass } \\
\text { Grams }\end{array}$ & $\begin{array}{c}\text { Through } \\
\text { Sieve } \\
\text { Mass }\end{array}$ & $\begin{array}{l}\text { Mass - } \\
\text { Column } \\
\text { Top }\end{array}$ & $\begin{array}{l}\text { Mass - } \\
\text { Column } \\
\text { Bottom }\end{array}$ & $\begin{array}{c}\text { Mass\% } \\
\text { Recovered }\end{array}$ \\
\hline \multicolumn{7}{|c|}{ Particles Greater than 125 micron } \\
\hline \multirow[t]{2}{*}{ S1 } & Resins & 14.4 & & 12.016 & 0.774 & 88.8 \\
\hline & Sludge & 105.612 & 96.4 & 1.68 & 6.57 & 99.1 \\
\hline \multirow[t]{2}{*}{$\$ 2$} & Resins & 14.4 & & 12.898 & 1.195 & 97.9 \\
\hline & Sludge & 105.599 & 96.78 & 1.79 & 6.64 & 99.6 \\
\hline \multirow[t]{2}{*}{ S3 } & Resins & 14.4 & & 12.88 & 0.44 & 92.5 \\
\hline & Sludge & 105.614 & 96.77 & 1.77 & 6.65 & 99.6 \\
\hline \multirow[t]{2}{*}{ S9 } & Resins & 14.4 & & 10.27 & 1.74 & 83.4 \\
\hline & Sludge & 105.61 & 95.15 & 1.878 & 7.388 & 98.9 \\
\hline \multicolumn{7}{|c|}{ Particles Greater than 300 micron } \\
\hline \multirow[t]{2}{*}{$\$ 4$} & Resins & 14.402 & & 12.75 & 0.6 & 92.7 \\
\hline & Sludge & 105.613 & 100.18 & 0.18 & 5.29 & 100.0 \\
\hline \multirow[t]{3}{*}{$\$ 10$} & Resins & 14.4 & & 10.391 & 1.488 & 82.5 \\
\hline & Sludge & 105.614 & 99.4 & 0.365 & 18.301 & 98.7 \\
\hline & Large sand & 14. & & & & \\
\hline \multirow[t]{3}{*}{ S11 } & Resins & 14.402 & & 11.293 & 0.28 & 80.4 \\
\hline & Sludge & 105.61 & 100.6 & 9 & 13.572 & 103.0 \\
\hline & Zeolon 900 & 14 & & & & \\
\hline
\end{tabular}

The mass percent of non-bead components recovered is generally higher than the percentage of bead mass recovered. This is attributed to the fact that the bead sluice separation method is not $100 \%$ effective and part of the bead mass is contained in the non-bead components. This is especially true of the S11 run, containing Zeolon 900, which did not separate very well from the beads in the column or the sluice.

\subsection{CONCLUSIONS/OBSERVATIONS}

The basic sludge simulant recipe experiments have demonstrated that it is possible to extract a nominal $95 \%$ resin bead mass in a elutriation column with a nominal 0.038 meter per second water flow rate. The non-bead sludge component entrained with the separated beads ranges from 0.15 to 1.4 percent of the total sludge dry mass.

The elutriation column will also lift non-bead sludge components to the top collection chamber. These components are mostly fine particles as evidenced by a factor of ten reduction in the nonbead component when the minimum particle size is increased from 125 microns to 300 microns. 


\section{K-Basin Sludge/Resin Bead Separation Test Report, HNF-3132, Rev. 0}

Sand particles larger than 420 microns only increase the column's lifted non-bead mass by a fractional percent. Large particles denser than sand will not rise and become entrained with the separated beads.

Zeolon 900 added to the sludge simulant produced the greatest mass percentage $(6.7 \%)$ of nonbead material lifted by the column in the test series. As with the large sand particles, a mass of Zeolon equal to the resin bead mass was added to the sludge simulant. The results of the only test suggest that $63 \%$ of the Zeolon mass will be lifted with the beads to the top of the elutriation column. 
K-Basin Sludge/Resin Bead Separation Test Report, HNF-3132, Rev. 0 Appendix A

Resin Bead Particle Size Distributions 
K Basin Sludge/Resin Bead Separation Test Report, HNF-3132, Rev. 0

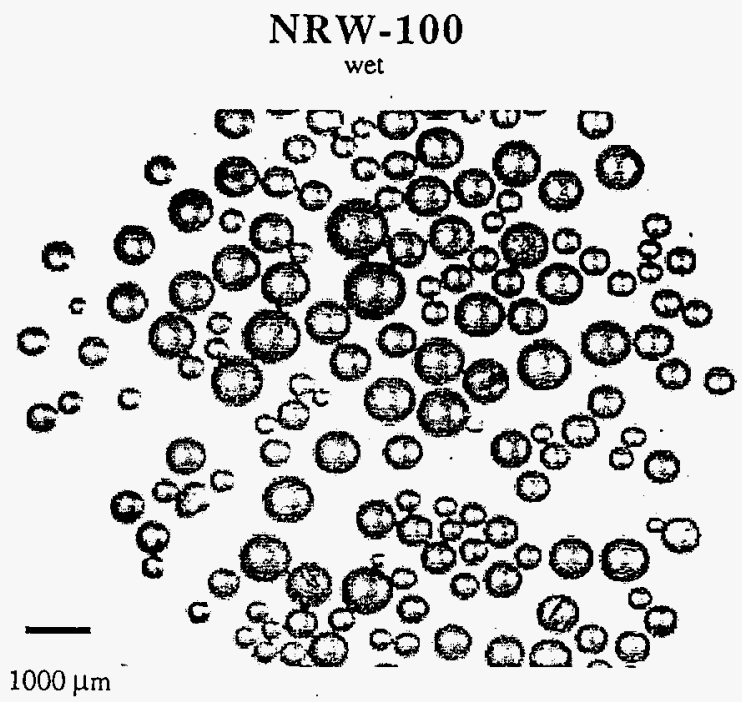

Descriptive Statistics

\begin{tabular}{c|r|r|r|r|r|r|} 
& \multicolumn{2}{c}{ Mean } & Std. Dev. Std. Error & \multicolumn{1}{c}{ Count - Minimum Maximum } \\
\cline { 2 - 7 } Equiv.Diam. $(\mu \mathrm{m})$ & 628.608 & 200.548 & 17.390 & 133 & 193.710 & 1192.900 \\
\hline
\end{tabular}

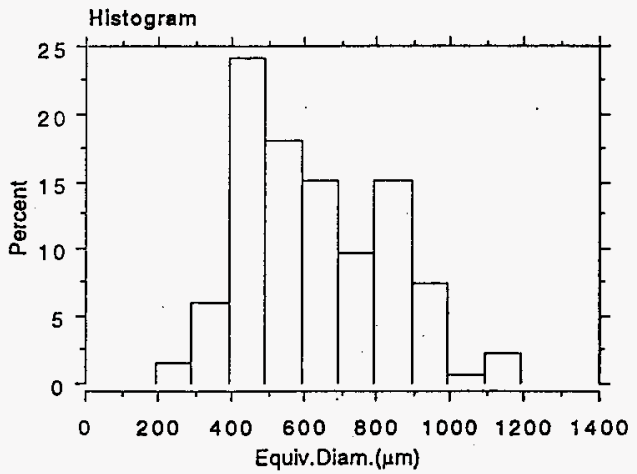


K Basin Sludge/Resin Bead Separation Test Report, HNF-3132, Rev. 0

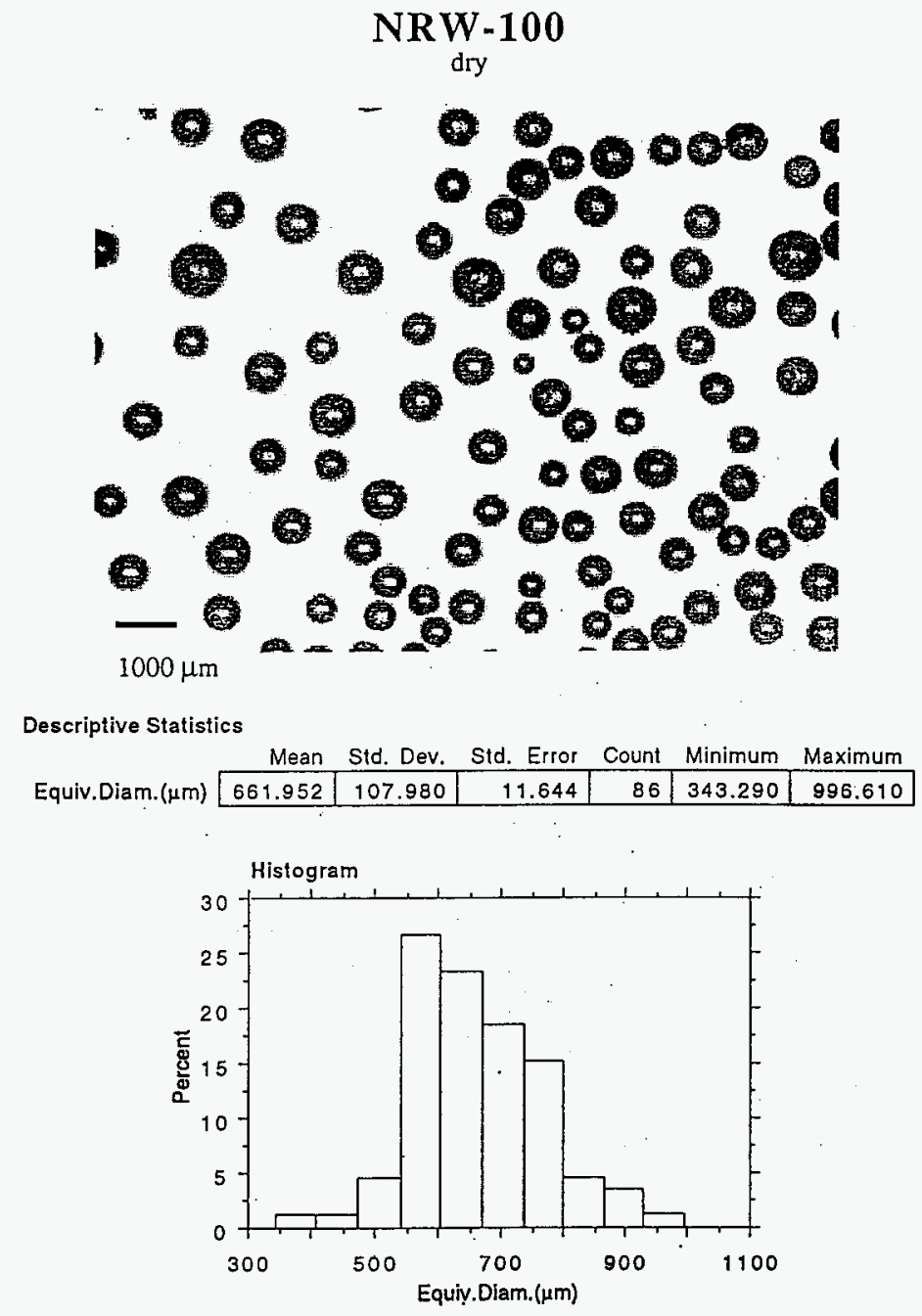


NRW-400

wet



Descriptive Statistics

\begin{tabular}{|c|c|c|c|c|c|c|}
\hline & Mean & Std. Dev. & Std. Error & Count & Minimum & Maximum \\
\hline Equiv.Diam. $(\mu \mathrm{m})$ & 788.052 & 190.875 & 18.036 & 112 & 41.940 & 1173.320 \\
\hline
\end{tabular}

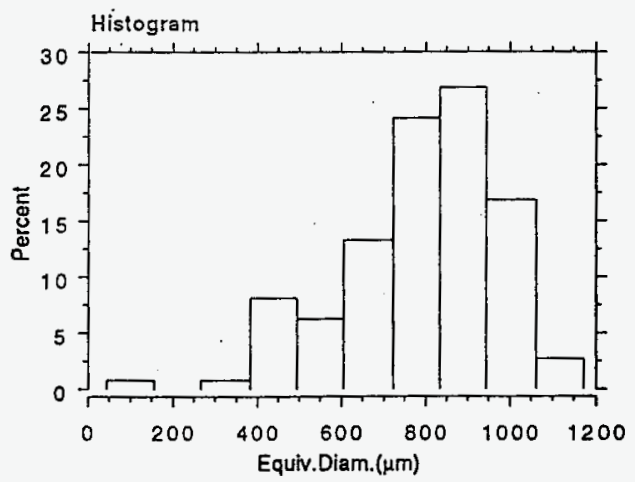


K Basin Sludge/Resin Bead Separation Test Report, HNF-3132, Rev. 0

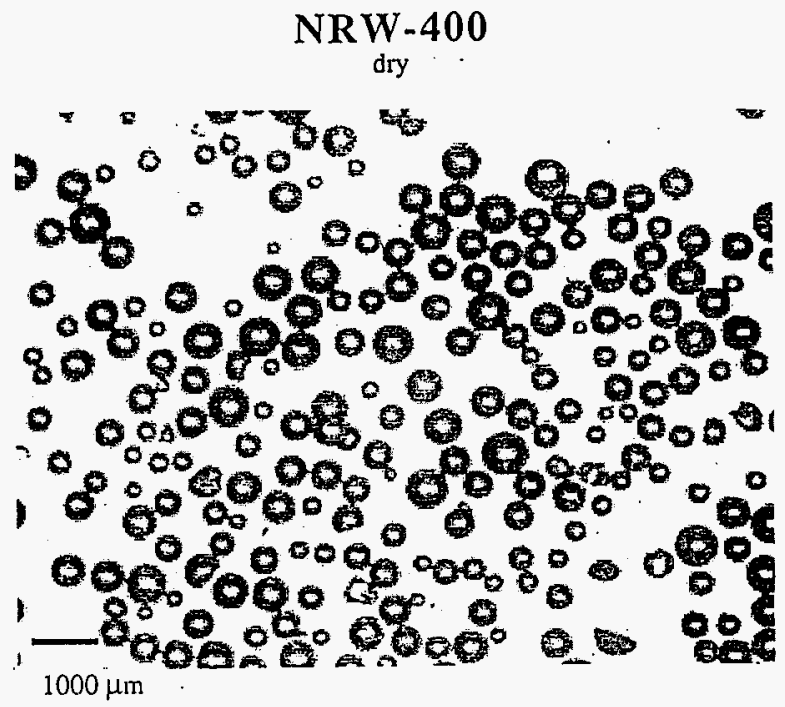

Descriptive Statistics

\begin{tabular}{c|r|r|r|r|r|r|} 
& \multicolumn{1}{c}{ Mean } & Std. Dev. Std. Error & Count & Minimum Maximum \\
\cline { 2 - 7 } Equiv.Diam. $(\mu \mathrm{m})$ & 505.559 & 125.430 & 8.574 & 214 & 238.480 & $\mathbf{8 1 2 . 8 9 0}$ \\
\hline
\end{tabular}

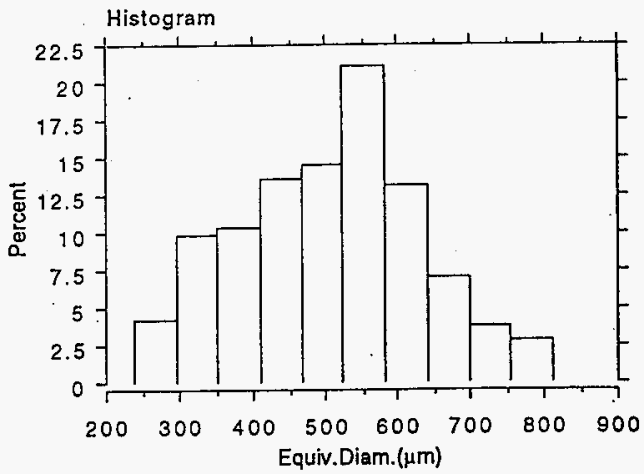


K Basin Sludge/Resin Bead Separation Test Report, HNF-3132, Rev. 0

\section{Appendix B}

Sludge Simulant for Organic Ion Exchange Resin Separation

8C720-98-JBD:001 


\section{K Basin Sludge/Resin Bead Separation Test Report, HNF-3132, Rev. 0}

KNUDCreptimp

TO: $\quad$ Thierry A. Flament

FROM: Jim Duncan

SUBJECT: $\quad$ Sludge Simulant for Organic Ion Exchange Resin Separation

DATE: 23 April 1998

CC: $\quad$ Mike Schliebe

\section{Purpose}

The purpose of this memorandum is to put forth a selection basis for the K Enet Berin foer and Wenel Pit simulant for the organic ion exchange resin (OIER) separation unit operation.

\section{References:}

Analysis of Sludge from Hanford K East Basin Floor and Weasel Pit, WHC-SP-1 182, April 1996.

K. Willeke and K.T. Whitby, J. Air Pol Control Assoc. 25:529(1975)

Kirk-Othmer, Encyclopedia of Chemical Technology, Vol. 1 (4th Ed), 1991

CRC Handbook of Chemistry and Physics, 53rd Ed., 1977-1978

Purolite Technical Data for NRW-37 Nuclear Grade Resin

\section{K East Sludge and Weasel Pit}

Using Table 4.3 Sludge Characterization Data -- Per Gram As-Settled Sludge (WHC-SP-1 182), the following mean values were extracted:

Table $1^{A}$

\begin{tabular}{|l|c|}
\hline \multicolumn{1}{|c|}{} \\
\hline Inorganic Elements & 13.4 \\
\hline Water & $56.8^{\mathrm{B}}$ \\
\hline Uranium & $2.5^{\mathrm{c}}$ \\
\hline Acid Insoluble Residue & 8.25 \\
\hline Total & 80.95 \\
\hline Major Inorganic Elements $(>1 \%)$ & Fe 10.8 \\
& $\mathrm{Al} 1.8$ \\
\hline
\end{tabular}

A The values are "as settled sludge", the expected water content of the retreived sludge is expected to be at a much higher concentration.

${ }^{B}$ Averaged values from $222 \mathrm{~S}$ Lab and PNNL.

${ }^{\mathrm{C}}$ ICP for total U, 222S Lab

The total analysis does not sum to $100 \%$. This is due to some elements not being andyzed, anch $a \mathrm{Si}$.

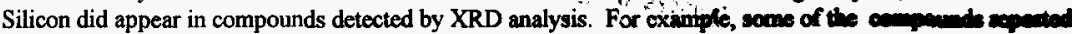




\section{K Basin Sludge/Resin Bead Separation Test Report, HNF-3132, Rev. 0}

were: $\mathrm{SiO}_{2}, \mathrm{Mg}_{3} \mathrm{Si}_{4} \mathrm{O}_{10}(\mathrm{OH})_{2}, \mathrm{Si}, \mathrm{CaAL}_{2} \mathrm{Si}_{2} \mathrm{O}_{8} \bullet 4 \mathrm{H}_{2} \mathrm{O}$. Also, the analysis ignored the man eccuriturion of bound water (water of hydration).

In Appendix I (WHC-SP-1 182), the particle size analysis indicated that the samples werenared "a

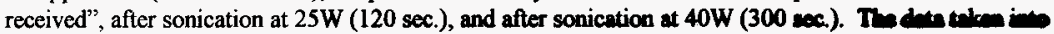
consideration for this report will be the "as received" data for simulant formulation. Trese of "es meciner

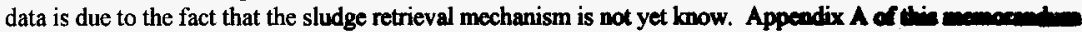
is an analysis of the graphical data presented in Appendix I of WHC-SP-1182, for the "es moduct and sonicated samples.

\section{Assumptions}

1. The separations will be based on physical parameters of the floor and weasel pit sludge.

2. The analyses as reported in WHC-SP-1182 are correct.

3. The fully loaded resin beads have a negligible increase in density (phone conversation with a Purolite Tech Representative, (800) 343-1500).

4. The mean mass balance difference of $19.05 \%$ ( $100 \%$ minus $80.95 \%$ from Table 1 ) is due to the mass contribution of compounds that were not considered for analyses (silicon for example), bound water, and ion exchange resin.

5. The resin is Purolite NRW-37 Nuclear Grade, mixed bed. The density of the hydrogen form (cation exchange resin) is 1.24. The density of the $\mathrm{Cl}$ form (anion exchange resin) is 1.10 . The mesh size is 16 to 40 , US standard screen ( 1.19 to $0.42 \mathrm{~mm}$, respectively).

6. Blow sand in the range of 2.5 to 10 microns (See Appendix B).

7. The only radionuclide of mass consequence is Uranium.

8. The simulant will be derived from the mean values as reported in Table 4.2 (WHC-SP-1182).

Adjustments will be made to mimic various conditions.

\section{Selection of the Simulant for OIER separation}

Table 2 Major Analytes and Simulants

\begin{tabular}{|c|c|c|c|}
\hline \multicolumn{4}{|c|}{ 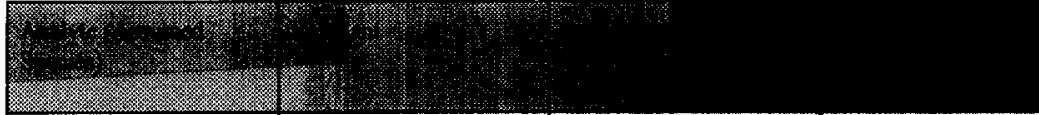 } \\
\hline Uranium $\left(\mathrm{UO}_{2}\right)$ & $\begin{array}{l}\text { Copper or } \\
\text { Chromium }\end{array}$ & 2.5 & $\begin{array}{l}\mathrm{Cu}=8.9 \\
\mathrm{Cr}=7.2(10.96)\end{array}$ \\
\hline Iron $\left(\mathrm{Fe}_{2} \mathrm{O}_{3}\right)$ & Iron Oxide & 10.8 & $5.24(5.24)$ \\
\hline Aluminum $\left(\mathrm{Al}_{2} \mathrm{O}_{3}\right)$ & Aluminum oxide & 1.8 & $3.97(3.97)$ \\
\hline Water & Water & 56.8 & $1.00(1.00)$ \\
\hline (2) & 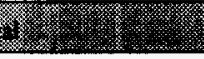 & 71.9 & \\
\hline Silicon $\left(\mathrm{SiO}_{2}\right)$ & $\begin{array}{l}\text { Blow Sand from K } \\
\text { Area, quartz }\end{array}$ & $\begin{array}{l}\text { Sand and the } \\
\text { combination of ion } \\
\text { exchange resin will }\end{array}$ & $2.64(2.64)$ \\
\hline $\begin{array}{l}\text { Organic Ion Exchange } \\
\text { Resin }\end{array}$ & $\begin{array}{l}\text { Purolite, NRW-37, } \\
\text { mixed bed (Volume } \\
\text { Ratio } 1.5 \text { anion to } \\
1.0 \text { cation }\end{array}$ & $\begin{array}{l}28.1 \text { per cent as } \\
\text { delineated in the OIER } \\
\text { test plan. }\end{array}$ & $\begin{array}{l}\text { Cation Resin }=1.24 \\
\text { Anion Resin }=1.10\end{array}$ \\
\hline
\end{tabular}




\section{K Basin Sludge/Resin Bead Separation Test Report, HNF-3132, Rev. 0}

\section{Laboratory Protocol for Simulant Make-up}

Materials:

- Resin: Resin beads will be obtained from either the vendor or from $K$ Basin operations.

- Aluminum oxide, chromium (or copper) will be obtained from a vendor in varying particle dimenaions.

- Iron oxide will be obtained by physically scraping "rusted material" found in storage yands around Bldg 305, 306E, etc.

- Blow sand will be obtained by retrieving the top 2 to $3 \mathrm{~mm}$ of sand around the K East basin.

- Water will be de-ionized, conductivity and $\mathrm{pH}$ will approximate that of $\mathrm{K}$ East basin.

Preparation:

- Grinding:

Individually, the iron oxide, aluminum oxide, and the blow sand will be subjected to a grinding phase arch a a ball mill or similar apparatus.

All material will individually be classified using a Rotap, with screen sizes from 25 US Standard meah (210 $\mu \mathrm{m}$ ) to 400 US Standard mesh ( $37 \mu \mathrm{m}$ ). Material passing the 400 mesh will be collocted as 400 minus and subjected to particle analysis.

- Simulant Make-up

Example:

The resin and sand are dependent variables and will vary according to the test protocol. However, the concentrations for iron oxide, aluminum oxide, water, and chromium will be fixed (assumption - normally and independently distributed, $(0,1))$.

For a total of $1000 \mathrm{~g}$ of simulant, and using the particle volume distribution for M13B (Appendix A, Table A-2, as received), particle diameters from $31 \mu \mathrm{m}$ to $352 \mu \mathrm{m}$ (mesh size of 400 to 48 reapectively). The following table can be derived. The weight of simulant should sum to the gram fraction of $1000 \mathrm{~g}$ as indicated. The difference between the independent variables and the total grems requined for thet particle range will be made from the dependent variables (resin and sand). 
Table 3 Example of Simulant Make-up (1000 g)

\begin{tabular}{|c|c|c|c|c|c|c|c|c|c|c|}
\hline Mesh Size & $24-35$ & $35-42$ & $48-60$ & $60-80$ & $120-80$ & $170-120$ & $230-170$ & $325-230$ & $400-325$ & $<400$ \\
\hline $\begin{array}{l}\text { Per Cent } \\
\text { Particles in } \\
\text { Range }\end{array}$ & $\begin{array}{r}8.94 \\
(89.4 \mathrm{~g})\end{array}$ & $\begin{array}{l}5.17 \\
(51.7 \mathrm{~g})\end{array}$ & $\begin{array}{l}2.2 \\
(22 \mathrm{~g})\end{array}$ & $\begin{array}{l}2.98 \\
(29.8 \mathrm{~g})\end{array}$ & $\begin{array}{l}2.8 \\
(28 \mathrm{~g})\end{array}$ & \begin{tabular}{|l}
3.15 \\
$(31.5 \mathrm{~g})$
\end{tabular} & $\begin{array}{l}4.38 \\
(43.8 \mathrm{~g})\end{array}$ & \begin{tabular}{|l}
6.13 \\
$(61.3 \mathrm{~g})$
\end{tabular} & $\begin{array}{l}8.23 \\
(82.3 \mathrm{~g})\end{array}$ & $\begin{array}{l}56.04 \\
(560 \mathrm{~g})\end{array}$ \\
\hline $\begin{array}{l}\mathrm{Al}_{2} \mathrm{O}_{3} @ \\
1.8 \%(\mathrm{~g})\end{array}$ & 1.61 & 0.93 & 0.39 & 0.54 & 0.50 & 0.57 & 0.79 & 1.1 & 1.48 & 10.1 \\
\hline $\begin{array}{l}\mathrm{Fe}_{2} \mathrm{O}_{3} @ \\
10.8 \%(\mathrm{~g})\end{array}$ & 9.66 & 5.58 & 2.37 & 3.22 & 3.02 & 3.40 & 4.73 & 6.62 & 8.89 & 60.52 \\
\hline $\begin{array}{l}\mathrm{Cr} @ \\
2.5 \%(\mathrm{~g}) \\
\end{array}$ & & & 0.55 & 0.83 & 0.98 & 1.38 & 1.9 & 2.4 & 2.5 & 14.6 \\
\hline Total & & & 9.4 & 23.7 & 28 & 39.5 & 55.3 & 69.7 & 72.6 & 419.2 \\
\hline $\begin{array}{l}\text { Difference } \\
\text { to be made } \\
\text { up with } \\
\text { Resin and } \\
\text { Blow Send } \\
\text { (g) }\end{array}$ & & & 3.6 & 9.3 & 11 & 15.5 & 23.7 & 27.3 & 28.4 & 163.8 \\
\hline
\end{tabular}


K Basin Sludge/Resin Bead Separation Test Report, HNF-3132, Rev. 0

Analyses of Particle Number Distribution and Particle Volume Distribution Gregh from Appendix I, WHC-SP-1182

Table A-1 Particle Number Distribution (WHC-SP-1182, Appendix I)

\begin{tabular}{|c|c|c|c|c|c|c|c|c|c|c|c|c|}
\hline & \multicolumn{3}{|c|}{ M13T } & \multicolumn{3}{|c|}{ M13B } & \multicolumn{3}{|c|}{ T20T } & & $20 \mathrm{BC}$ & \\
\hline $\begin{array}{l}\text { Particle } \\
\text { Dia. }(\mu \mathrm{m})\end{array}$ & \multicolumn{3}{|c|}{ Per Cent in Range } & \multicolumn{3}{|c|}{ Per Cent in Range } & \multicolumn{3}{|c|}{ Per Cent in Range } & \multicolumn{3}{|c|}{ Per Cont in R- } \\
\hline & $\begin{array}{l}40 \\
W\end{array}$ & $\begin{array}{l}25 \\
W\end{array}$ & $\begin{array}{l}\text { As } \\
\text { Received }\end{array}$ & $\begin{array}{l}40 \\
W\end{array}$ & $\begin{array}{l}25 \\
W\end{array}$ & $\begin{array}{l}\text { As } \\
\text { Received }\end{array}$ & $\begin{array}{l}40 \\
W\end{array}$ & $\begin{array}{l}25 \\
W\end{array}$ & $\begin{array}{l}\text { As } \\
\text { Received }\end{array}$ & $\begin{array}{l}40 \\
W\end{array}$ & $\begin{array}{l}25 \\
W\end{array}$ & \\
\hline $\begin{array}{l}0.172 \text { to } \\
0.243\end{array}$ & 35 & - & - & - & .. & - & 60 & 64 & - & 48 & 37 & - \\
\hline $\begin{array}{l}0.243 \text { to } \\
0.344\end{array}$ & 38 & 60 & -- & 60 & 57 & - & 25 & 23 & - & 34 & 41 & 33 \\
\hline $\begin{array}{l}0.344 \text { to } \\
0.486\end{array}$ & 13 & 21 & - & 23 & 23 & -. & 8 & 6 & - & 11 & 14 & 42 \\
\hline $\begin{array}{l}0.486 \text { to } \\
0.688\end{array}$ & 7 & 9 & 47 & 9 & 10 & 51 & 4 & 2 & 55 & 5 & 6 & 14 \\
\hline $\begin{array}{l}0.688 \text { to } \\
0.972\end{array}$ & 3 & 5 & 27 & 6 & 8 & 25 & & & 23 & & & 7 \\
\hline $\begin{array}{l}0.972 \text { to } \\
1.375\end{array}$ & 1 & 3 & 13 & 1 & & 12 & & & 7 & & & 3 \\
\hline $\begin{array}{l}1.375 \text { to } \\
1.946\end{array}$ & & & 7 & & & 5 & & & 4 & & & 1 \\
\hline $\begin{array}{l}1.946 \text { to } \\
2.750\end{array}$ & & & 3 & & & 3 & & & 3 & & & \\
\hline $\begin{array}{l}2.750 \text { to } \\
3.889\end{array}$ & & & 2 & & & 3 & & & 8 & & & \\
\hline $\begin{array}{l}3.889 \text { to } \\
5.500\end{array}$ & & & 1 & & & 1 & & & & & & \\
\hline Total & 98 & 98 & 100 & 99 & 98 & 100 & 97 & 95 & 100 & 98 & 98 & 100 \\
\hline
\end{tabular}


K Basin Sludge/Resin Bead Separation Test Report, HNF-3132, Rev. 0

Particle Volume Distribution (WHC-SP-1182, Appendix I)

\begin{tabular}{|c|c|c|c|c|c|c|c|c|c|c|c|c|}
\hline & \multicolumn{3}{|c|}{ M13T } & \multicolumn{3}{|c|}{ M13B } & \multicolumn{3}{|c|}{ T20T } & \multicolumn{3}{|c|}{ T20B(Duplinesc) } \\
\hline \multirow{2}{*}{$\begin{array}{l}\text { Particle Dia. } \\
(\mu \mathrm{m})\end{array}$} & \multicolumn{3}{|c|}{ Per Cent in Range } & \multicolumn{3}{|c|}{ Per Cent in Range } & \multicolumn{3}{|c|}{ Per Cent in Range } & \multicolumn{3}{|c|}{ Per Cent in Ronge } \\
\hline & $\begin{array}{l}40 \\
W\end{array}$ & $\begin{array}{l}25 \\
W\end{array}$ & $\begin{array}{l}\text { As } \\
\text { Received }\end{array}$ & $\begin{array}{l}40 \\
W\end{array}$ & $\begin{array}{l}25 \\
W\end{array}$ & $\begin{array}{l}\text { As } \\
\text { Received }\end{array}$ & $\begin{array}{l}40 \\
W\end{array}$ & $\begin{array}{l}25 \\
W\end{array}$ & $\begin{array}{l}\text { As } \\
\text { Received }\end{array}$ & $\begin{array}{l}40 \\
W\end{array}$ & $\begin{array}{l}25 \\
W\end{array}$ & $\begin{array}{l}\text { A } \\
\text { Peoninen }\end{array}$ \\
\hline $\begin{array}{l}0.172 \text { to } \\
0.243\end{array}$ & 0.75 & -- & -- & -- & -- & - & 1.8 & 1.7 & 1.2 & 0.9 & 0.8 & - \\
\hline $\begin{array}{l}0.243 \text { to } \\
0.344\end{array}$ & 1.80 & 0.8 & - & 1.0 & 0.4 & - & 2.1 & 1.8 & 1.3 & 2.0 & 1.8 & 1.0 \\
\hline $\begin{array}{l}0.344 \text { to } \\
0.486\end{array}$ & 1.90 & 1.0 & 0.3 & 1.0 & 1.0 & 0.8 & 2.0 & 1.6 & 1.2 & 2.0 & 1.8 & 1.0 \\
\hline $\begin{array}{l}0.486 \text { to } \\
0.688\end{array}$ & 1.60 & 1.1 & 0.8 & 1.3 & 1.1 & 0.9 & 2.1 & 1.5 & 1.3 & 1.9 & 1.8 & 1.0 \\
\hline $\begin{array}{l}0.688 \text { to } \\
0.972\end{array}$ & 2.6 & 1.6 & 1.1 & 2.0 & 1.7 & 1.2 & 2.7 & 1.9 & 1.5 & 2.7 & 2.1 & 1.4 \\
\hline $\begin{array}{l}0.972 \text { to } \\
1.375\end{array}$ & 3.4 & 2.0 & 1.6 & 2.7 & 2.1 & 1.6 & 3.7 & 2.4 & 2.1 & 3.6 & 2.8 & 1.9 \\
\hline $\begin{array}{l}1.375 \text { to } \\
1.946\end{array}$ & 4.0 & 3.2 & 1.9 & 3.2 & 2.5 & 2.1 & 3.8 & 2.8 & 2.3 & 3.9 & 3.2 & 2.1 \\
\hline $\begin{array}{l}1.946 \text { to } \\
2.750\end{array}$ & 5.0 & 4.2 & 2.3 & 3.8 & 3.5 & 2.6 & 3.9 & 3.7 & 2.2 & 4.2 & 3.6 & 2.4 \\
\hline $\begin{array}{l}2.750 \text { to } \\
3.889\end{array}$ & 6.3 & 5.5 & 4.1 & 4.8 & 4.5 & 3.8 & 5.1 & 4.6 & 4.0 & 4.9 & 4.2 & 3.2 \\
\hline $\begin{array}{l}3.889 \text { to } \\
5.500\end{array}$ & 7.4 & 7.7 & 5.9 & 6.3 & 6.0 & 5.1 & 6.5 & 6.1 & 5.4 & 5.5 & 4.7 & 4.0 \\
\hline $\begin{array}{l}5.500 \text { to } \\
7.778\end{array}$ & 10.8 & 10.6 & 8.7 & 8.1 & 7.7 & 6.3 & 8.1 & 7.8 & 6.5 & 7.4 & 6.5 & 5.0 \\
\hline $\begin{array}{l}7.778 \text { to } \\
11.000\end{array}$ & 11.5 & 11.6 & 10.3 & 8.6 & 8.2 & 7.1 & 8.6 & 8.3 & 7.5 & 7.8 & 6.9 & 5.2 \\
\hline $\begin{array}{l}11.000 \text { to } \\
15.560\end{array}$ & 11.8 & 11.8 & 11.0 & 8.8 & 8.7 & 8.0 & 9.3 & 9.4 & 8.5 & 7.9 & 7.4 & 5.8 \\
\hline $\begin{array}{l}15.560 \text { to } \\
22.000\end{array}$ & 11.9 & 13.5 & 14.7 & 10.1 & 10.0 & 9.0 & $\begin{array}{l}10 . \\
5 \\
\end{array}$ & $\begin{array}{l}11 . \\
0\end{array}$ & 10.2 & 8.4 & 8.2 & 6.7 \\
\hline $\begin{array}{l}22.000 \text { to } \\
31.100\end{array}$ & 9.3 & 11.4 & 14.7 & 10.9 & 11.1 & 10.1 & 9.6 & $\begin{array}{l}10 . \\
6\end{array}$ & 10.4 & 7.8 & 8.3 & 7.5 \\
\hline $\begin{array}{l}31.100 \text { to } \\
44.000\end{array}$ & 5.2 & 6.9 & 10.1 & 10.3 & 11.4 & 10.1 & 7.1 & 7.1 & 9.0 & 7.8 & 8.3 & 8.2 \\
\hline
\end{tabular}


K Basin Sludge/Resin Bead Separation Test Report, HNF-3132, Rev. 0

\begin{tabular}{|l|l|l|l|l|l|l|l|l|l|l|l|l|}
\hline $\begin{array}{l}44.000 \text { to } \\
62.230\end{array}$ & 2.5 & 3.2 & 5.6 & 7.9 & 9.4 & 9.7 & 4.9 & 5.5 & 6.7 & 5.8 & 6.8 & 5.9 \\
\hline $\begin{array}{l}62.230 \text { to } \\
88.000\end{array}$ & 1.2 & 1.8 & 2.7 & 4.7 & 5.9 & 7.9 & 2.0 & 2.7 & 4.5 & 4.5 & 5.4 & 5.1 \\
\hline $\begin{array}{l}88.000 \text { to } \\
124.50\end{array}$ & 0.6 & 0.8 & 0.9 & 3.2 & 4.1 & 5.5 & 1.6 & 2.2 & 3.3 & 3.4 & 4.6 & 4.8 \\
\hline $\begin{array}{l}124.50 \text { to } \\
176.00\end{array}$ & & & 1.3 & 1.5 & 1.9 & 3.9 & 1.0 & 1.8 & 2.3 & 2.5 & 3.5 & 5.2 \\
\hline $\begin{array}{l}176.00 \text { to } \\
248.900\end{array}$ & & & & 0.7 & 0.9 & 3.3 & 1.2 & 2.2 & 2.3 & 1.1 & 1.7 & 4.5 \\
\hline $\begin{array}{l}248.900 \text { to } \\
352.00\end{array}$ & & & & & & 1.3 & 1.7 & 1.8 & 3.2 & 1.5 & 2.0 & 3.0 \\
\hline $\begin{array}{l}352.00 \text { to } \\
497.00\end{array}$ & & & & & & & & & 2.2 & 3.8 & 4.8 & 9.6 \\
\hline $\begin{array}{l}497.00 \text { to } \\
704.00\end{array}$ & & & & & & & & & & & & 10.2 \\
\hline \begin{tabular}{l} 
Total \\
\hline
\end{tabular} & 99.6 & 98.7 & 98 & $\begin{array}{l}100 . \\
9\end{array}$ & $\begin{array}{l}102 . \\
1\end{array}$ & 100.3 & 99. & $\begin{array}{l}98 . \\
5\end{array}$ & 99.1 & 101. & 101. & 104.7 \\
\hline
\end{tabular}




\title{
K Basin Sludge/Resin Bead Separation Test Report, HNF-3132, Rev. 0
}

\author{
Basis for Blow Sand Particle Size
}

Reference:

Kirk-Othmer, Encyclopedia of Chemical Technology, Vol. 1 (4th Ed.), 1991

K. Willeke and K. T. Whitby, J. Air Pol Control Assoc. 25:529(1975)

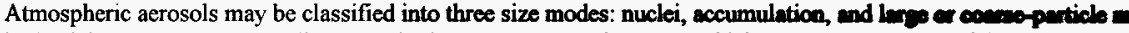
bulk of the aerosol mass usually occurs in the 0.1 to $10 \mu \mathrm{m}$ size range which encompasses mat of the acoumplaticum

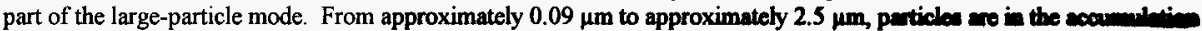
mode, while particles in the $2.5 \mu \mathrm{m}$ to $10 \mu \mathrm{m}$ range tend to have appreciable deposition velocition (Kirt-Othmer).

The characteristics of wind blown dust are (Willeke \& Whitby):

Table B-1 Aerosol Characteristics of $2.5 \mu \mathrm{m}$ to $10 \mu \mathrm{m}$ Particles

\begin{tabular}{|l|l|}
\hline Source & Wind Blown Dust \\
\hline Fate & Deposit \\
\hline Atmospheric Lifetime & Hours \\
\hline
\end{tabular}


K Basin Sludge/Resin Bead Separation Test Report, HNF-3132, Rev. 0

\section{Appendix C}

\begin{tabular}{|c|c|c|c|c|c|c|c|c|c|}
\hline \multirow{2}{*}{\multicolumn{3}{|c|}{\begin{tabular}{|c|} 
\\
Table C-1. S \\
Balance: Mettler PM1200
\end{tabular}}} & & & & & & & \\
\hline & & & \multicolumn{7}{|c|}{ Measurements by BohL } \\
\hline \multicolumn{3}{|c|}{$\begin{array}{l}\text { Calibration Code 752-06-01-001 } \\
\text { Calibration Date 10/31/97 }\end{array}$} & \multicolumn{7}{|c|}{ Dry Sludge Stimulant Batch } \\
\hline \multicolumn{3}{|c|}{ Calihration Exnires 10/28/98 } & 1 & 2 & 3 & 4 & 9 & 10 & 11 \\
\hline Component & Micron Size & Target & Actual & Actual & Actual & Actual & Actual & Actual & Actual \\
\hline \multirow[t]{8}{*}{$\widehat{\mathrm{Al}_{2} \mathrm{O}_{3}}$} & 297 to 420 & 0.567 & 0.568 & 0.567 & 0.568 & 0.568 & 0.567 & 0.567 & 0.567 \\
\hline & 210 to 297 & 0.239 & 0.24 & 0.24 & 0.239 & 0.239 & 0.24 & 0.24 & 0.238 \\
\hline & 125 to 210 & 0.398 & 0.398 & 0.398 & 0,399 & 0.399 & 0.398 & 0.399 & 0.398 \\
\hline & 90 to 125 & 0.328 & 0.328 & 0.328 & 0,328 & 0.329 & 0.329 & 0.329 & 0.328 \\
\hline & 63 te 90 & 0.462 & 0.462 & 0.462 & 0.462 & 0.463 & 0.463 & 0.463 & 0.463 \\
\hline & 45 to 63 & 0.787 & 0.788 & 0.786 & 0.787 & 0.788 & 0.788 & 0.788 & 0.788 \\
\hline & 38 to 45 & 1.134 & 1.134 & 1.135 & 1.134 & 1.134 & 1.134 & 1.133 & 1.134 \\
\hline & $<38$ & 11686 & 11.685 & 11.686 & 11.685 & 11.68 & 11.68 & 11.68 & 11.687 \\
\hline \multirow[t]{8}{*}{$\mathrm{Fe}_{2} \mathrm{O}_{3}$} & 297 to 420 & 1.744 & 1.745 & 1.745 & 1.744 & 1.743 & 1.744 & 1.744 & 1.744 \\
\hline & 210 to 297 & 0.734 & 0.736 & 0.734 & 0.736 & 0.735 & 0.734 & 0,735 & 0.735 \\
\hline & 125 to 210 & 1.224 & 1.225 & 1.226 & 1.224 & 1.224 & 1.225 & 1.225 & 1.225 \\
\hline & 90 to 125 & 1.01 & 1.011 & 1.009 & 1.012 & 1.01 & 1.009 & 1.01 & 1.011 \\
\hline & 63 to 90 & 1.423 & 1.423 & 1.421 & 1.425 & 1.423 & 1.424 & 1.425 & 1.423 \\
\hline & 45 to 63 & 2.421 & 2.42 & 2.421 & 2,422 & 2.423 & 2.422 & 2421 & 2.42 \\
\hline & 38 to 45 & 3.488 & 3487 & 3.487 & 3.488 & 3.487 & 3.489 & 3.489 & 3.488 \\
\hline & $<38$ & 35.956 & 35.957 & 35.957 & 35.957 & 35.95 & 35.95 & 35.95 & 35.956 \\
\hline \multirow[t]{2}{*}{ Copper } & $>420$ & 2.566 & 2.565 & 2.566 & 2.566 & 2.567 & 2.566 & 2.567 & 2.566 \\
\hline & $<10$ & 11.833 & 11.834 & 11.834 & 11.835 & 11.83 & 11.83 & 11.83 & 11.833 \\
\hline \multirow[t]{8}{*}{ Blow Sand } & 297 to 420 & 1.003 & 1.005 & 1.003 & 1.002 & 1.003 & 1.003 & 1.004 & 1.004 \\
\hline & 210 to 297 & 0.422 & 0.423 & 0.422 & 0.423 & 0.424 & 0.423 & 0.422 & 0.422 \\
\hline & 125 to 210 & 0.704 & 0.705 & 0.704 & 0.704 & 0.704 & 0.705 & 0.703 & 0.705 \\
\hline & 90 to 125 & 0.581 & 0.582 & 0.581 & 0.58 & 0.582 & 0.58 & 0.582 & 0.581 \\
\hline & 63 to 90 & 0.818 & 0.82 & 0.816 & 0.82 & 0819 & 0.818 & 0.819 & 0.819 \\
\hline & 45 to 63 & 1.392 & 1.393 & 1.392 & 1.392 & 1.392 & 1.392 & 1.394 & 1.393 \\
\hline & 38 to 45 & 2.006 & 2.005 & 2.004 & 2.008 & 2.005 & 2.007 & 2.007 & 2.007 \\
\hline & $<38$ & 20674 & 20.673 & \begin{tabular}{|l|}
20.675 \\
\end{tabular} & 20.674 & 20.67 & 20.67 & 20.67 & 20.675 \\
\hline Resin & As received & 14.4 & 14.4 & 14.4 & 14.4 & 14.4 & 14.40 & 14.4 & 14.402 \\
\hline \multicolumn{2}{|c|}{$\begin{array}{l}\text { * Mass measured after } \\
\text { vacuum drying } \\
\text { hydrated material }\end{array}$} & mater & & & & & & 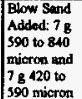 & 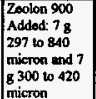 \\
\hline
\end{tabular}




\section{Rotameter Calibration}

\section{Appendix D}

The rotameter was calibrated by pumping water through the instrument to fill a $2000 \mathrm{ml}$ graduated cylinder and recording the time required at various flow indications. The pump speed is adjusted to provide the desired rotameter reading while the water flow is directed away from the graduated cylinder. Once the desired flow is established, the water is directed into the cylinder while simultaneously starting a stopwatch. As the cylinder approaches full, the stopwatch is stopped while simultaneously the water is directed away from the cylinder. The rotameter reading, time and water volume are recorded. This is repeated at each rotameter increment throughout the range of interest. The volume flow rate is calculated by dividing the water volume by time. The data is entered into a spreadsheet to obtain the equation of a linear regression line.

The elutriation column velocity is calculated by dividing the volume flow rate by the cross sectional area of the column. Column velocities are calculated using volume flow rates predicted by the linear regression line equation:

$$
\mathrm{ml} / \mathrm{sec}=0.6687 \times(\text { rotameter reading })+2.5118
$$

\begin{tabular}{|c|c|c|c|c|c|c|}
\hline \multicolumn{7}{|c|}{ Table D-1. Rotameter Calibration } \\
\hline \multicolumn{4}{|c|}{$\begin{array}{l}\text { Manufacture: Brooks Instrument Div. } \\
\text { Model Number 1307-08E1B1A } \\
\text { Serial Number 7806H54274 } \\
\text { Calibration Date 23-Jun-98 } \\
\text { Calibrated By: Don Squier }\end{array}$} & \multicolumn{3}{|c|}{\begin{tabular}{|l|}
\multicolumn{1}{|c|}{ Column Velocity } \\
\\
Column Inside Diameter - Inches 1.365 \\
Column Cross Section - $\mathrm{cm}^{2} 9.4411$ \\
\end{tabular}} \\
\hline $\begin{array}{c}\text { Rotameter } \\
\text { Reading }\end{array}$ & Seconds & Volume $\mathrm{ml}$ & $\begin{array}{c}\text { Flow Rate } \\
\mathrm{ml} / \mathrm{sec}\end{array}$ & $\begin{array}{l}\text { Regression } \\
\text { Line }\end{array}$ & $\begin{array}{l}\text { Column } \\
\text { Velocity }\end{array}$ & $\begin{array}{l}\text { Column } \\
\text { Velocity }\end{array}$ \\
\hline 42 & 65.3 & 2005 & 30.70 & 30.60 & 3.241 & 0.032 \\
\hline 44 & 62.5 & 1990 & 31.84 & 31.93 & 3.383 & 0.034 \\
\hline 46 & 60 & 1987 & 33.12 & 33.27 & 3.524 & 0.035 \\
\hline 48 & 57.5 & 1992 & 34.64 & 34.61 & 3.666 & 0.037 \\
\hline 50 & 55 & 1987 & 36.13 & 35.95 & 3.807 & 0.038 \\
\hline 52 & 53.4 & 1990 & 37.27 & 37.28 & 3.949 & 0.039 \\
\hline 54 & 516 & 1990 & 38.57 & 38.62 & 4.091 & 0.041 \\
\hline
\end{tabular}


K Basin Sludge/Resin Bead Separation Test Report, HNF-3132, Rev. 0

Rotameter CalloratJon

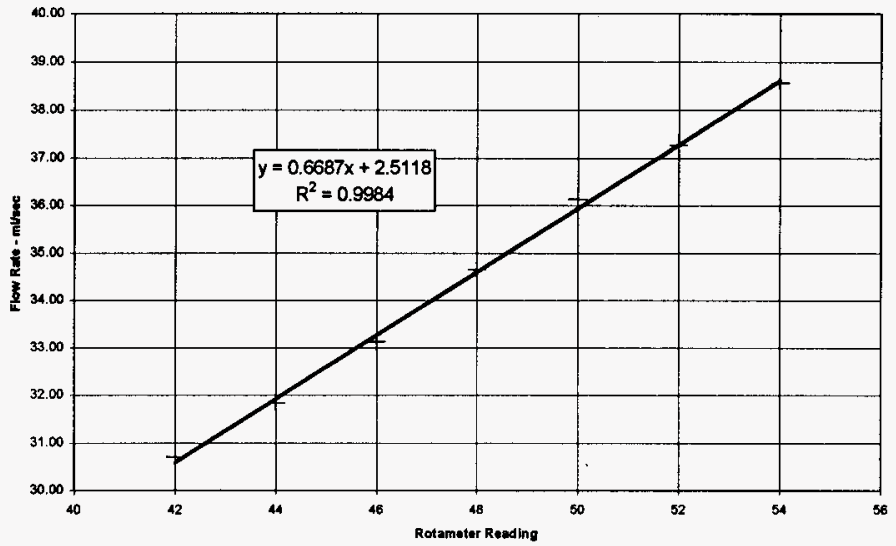

Figure D-1. Rotameter Calibration 
K Basin Sludge/Resin Bead Separation Test Report, HNF-3132, Rev. 0

\section{Appendix E}

\begin{tabular}{|c|c|c|c|c|c|c|}
\hline $\begin{array}{c}\text { Rotameter } \\
\text { Indication } \\
-\% \text { Flow } \\
(100 \%= \\
\sim 1.09 \\
\text { GPM) }\end{array}$ & $\begin{array}{l}\text { Grams } \\
\text { lifted to } \\
\text { column } \\
\text { top }\end{array}$ & $\begin{array}{l}\text { Grams } \\
\text { falling to } \\
\text { column } \\
\text { bottom }\end{array}$ & $\begin{array}{c}\text { Flow Rate } \\
\text { - ml/sec }\end{array}$ & \begin{tabular}{|c}
$\begin{array}{c}\text { Velocity } \\
\text { in Column } \\
- \text { cm/sec }\end{array}$ \\
\end{tabular} & \begin{tabular}{|c|} 
Velocity \\
in Column \\
$-\mathrm{m} / \mathrm{s}$
\end{tabular} & $\begin{array}{l}\% \text { Resin } \\
\text { lifted to } \\
\text { column } \\
\text { top }\end{array}$ \\
\hline 40 & 8.41 & 3.93 & 29.260 & 3.099 & 0.031 & 68.2 \\
\hline 50 & 12.58 & 0.46 & 35.947 & 3.807 & 0.038 & 96.5 \\
\hline 46 & 14.35 & 1.61 & 33.272 & 3.524 & 0.035 & 89.9 \\
\hline 52 & 13.1 & 0.28 & 37.284 & 3.949 & 0.039 & 97.9 \\
\hline
\end{tabular}




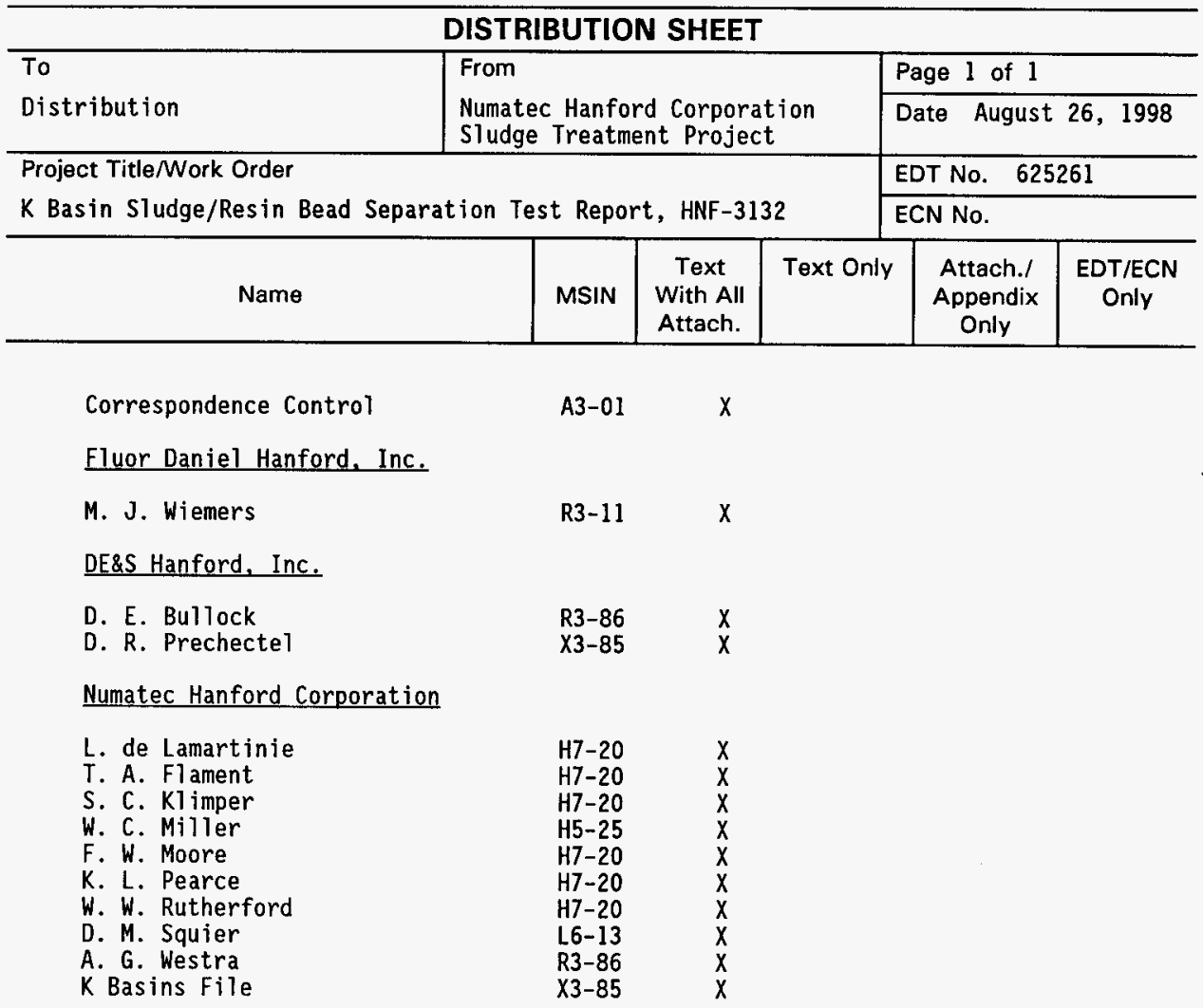

